\title{
Association between tumour characteristics and HER-2/neu by immunohistochemistry in 1362 women with primary operable breast cancer
}

\author{
H J Huang, P Neven, M Drijkoningen, R Paridaens, H Wildiers, E Van Limbergen, P Berteloot, \\ F Amant, I Vergote, M R Christiaens
}

See end of article for authors' affiliations ......................

Correspondence to: Dr P Neven, Division of Gynaecological Oncology in Department of Obstetrics and Gynaecology, University Hospital Leuven Herestraat 49, 3000 Leuven, Belgium; Patrick.Neven@ uz.kuleuven.ac.be

Accepted for publication 2 November 2004

\begin{abstract}
Aims: To investigate the association between tumour characteristics and HER-2/neu by immunohistochemistry in primary operable breast cancer.

Methods: The association between HER-2/neu and other clinicopathological factors was evaluated in 1362 consecutive patients with primary breast cancer treated between 2000 and July 2003 in one centre. Microscopic tumour size, fumour grade, lymph node status, patient's age, oestrogen receptor (ER), progesterone receptor (PR), and joint ER/PR status were evaluated, using the $\chi^{2}$ test for univariate analysis and logistic regression for multivariate analysis. The hormone receptors and HER-2/neu were studied immunohistochemically. Using the HER-2/neu DAKO scoring system, scores of $0,1+$, or $2+$ were defined as negative and $3+$ as positive. Data for DAKO scores $2+/ 3+$ versus $0 / 1+$ are also presented.

Results: Hormone receptor negative breast cancers were more often HER-2/neu positive than hormone receptor positive cancers, both for ER $(28.7 \%$ v $6.8 \%)$ and PR (19.9\% v 5.9\%). In multivariate analysis, both ER, PR, and tumour grade were independently associated with HER-2/neu. In ER+ tumours, HER-2/ neu overexpression was significantly lower in $\mathrm{PR}^{+}$than in $\mathrm{PR}^{-}$cases $(11.5 \% \vee 5.4 \%)$. HER-2/neu overexpression (2.7\%) was lowest in the large subgroup of $E R^{+} \mathrm{PR}^{+}$tumours with low tumour grade (grade $1-2)$, comprising $46.1 \%$ of all patients.

Conclusions: ER, PR, and tumour grade are independent predictors for HER-2/neu overexpression in women with primary operable breast cancer. ER and PR are negatively associated with HER-2/neu, whereas tumour grade is positively associated with HER-2/neu. In women with $\mathrm{ER}^{+}$tumours, PR status also affects the likelihood of HER-2/neu expression.
\end{abstract}

$\mathrm{T}$ he HER-2 gene encodes a $185 \mathrm{kDa}$ transmembrane phosphoglycoprotein with tyrosine kinase activity and is a member of the human epidermal growth factor receptor gene family. ${ }^{1}$ Cells transfected with HER-2/neu acquire a more malignant phenotype, with stimulation of cell proliferation, invasion, and metastasis. ${ }^{2}$ This has been confirmed in the clinic: women with HER-2/neu positive breast cancer have a worse prognosis than those with HER-2/neu negative cancers; this is also true for TINOMO tumours. ${ }^{3-6}$ Furthermore, HER-2/neu overexpression has been correlated with poor prognostic tumour characteristics such as higher histological grade, $\mathrm{S}$ phase fraction, increased tumour size, number of involved lymph nodes, lymphoid infiltration, p53 mutation, absence of bcl-2, absence of lobular histology, and negative or lower oestrogen receptor (ER) expression. ${ }^{7-15}$ As a consequence, several, but not all, studies have confirmed that HER-2/neu overexpressing tumours show a lower response to tamoxifen in metastatic or early breast cancer. ${ }^{16-21}$

\begin{abstract}
"Women with HER-2/neu positive breast cancer have a worse prognosis than those with HER-2/neu negative cancers"
\end{abstract}

Several techniques are available for the genetic testing of HER-2/neu amplification. Fluorescence in situ hybridisation (FISH) has become popular over the past few years because it is a reliable method. Semiquantitative measurement using immunohistochemistry (IHC) for the HER-2/neu membrane receptor protein can also accurately predict gene amplification. $^{22}$ FISH for HER-2/neu has a higher failure rate and reagent cost than IHC, and it takes longer to carry out and interpret than IHC. Testing for HER-2/neu is currently standard practice because it has a prognostic role and predicts response to the anti-HER-2/neu antibody, trastuzumab, which offers an extra treatment option, in monotherapy and also together with chemotherapy in women with metastatic disease. ${ }^{23-25}$ Trastuzumab is currently under extensive evaluation in major clinical trials and HER-2/neu is being tested as a predictor of response to other treatments in large prospective clinical outcome studies.

It has recently been suggested in a univariate model that there is an inverse relation between the expression of the progesterone receptor (PR) and HER-2/neu in women with $\mathrm{ER}^{+}$breast cancer. ${ }^{11}{ }^{12}$ However, $\mathrm{ER}^{+}$breast cancers that are $\mathrm{PR}^{-}$are more likely to be of a high grade, resistant to tamoxifen, and more aggressive, independent of treatment. ${ }^{26-28}$ Therefore, it is not clear whether tumour grade and PR remain independent predictors for HER-2/neu in a multivariate model. We examined in a multivariate analysis the relation between HER-2/neu overexpression and other clinicopathological factors in women with operable breast cancer.

\section{MATERIALS AND METHODS}

Charts from 1688 consecutive women with breast cancer, treated between January 2000 and July 2003 at Leuven University Hospital, Belgium, were retrospectively evaluated.

Abbreviations: $\mathrm{Cl}$, confidence interval; $\mathrm{ER}$, oestrogen receptor; $\mathrm{FISH}$, fluorescence in situ hybridisation; IHC, immunohistochemistry; OR, odds ratio; PR, progesterone receptor 
Women who had recurrent tumours or received neoadjuvant treatment, in addition to those with missing data on the tumour characteristics, were excluded; 1362 patients remained. The following factors were evaluated: patient's age at diagnosis, tumour size, tumour grade, axillary lymph node status, ER, PR, and HER-2/neu status.

IHC staining for ER, PR, and HER-2/neu was carried out according to the Envision method as a standard procedure for clinical purposes using the NCL-ER-6F11/2, NCL-PgR-312, and CBll primary monoclonal antibodies, respectively. ER, PR, and HER-2/neu IHC staining was evaluated semiquantitatively. Using the $\mathrm{H}$ score for $\mathrm{ER}$ and $\mathrm{PR}$, a negative result was defined as a score of $\leqslant 50$, weakly positive as 51-100, moderately positive as 101-200, and strongly positive as $>200$. The DAKO scoring system for HER-2/neu was defined as negative for scores of $0,1+$, or $2+$ and positive for tumours with a score of $3+$. In a small subgroup $(\mathrm{n}=41)$ of the 149 women with a HER-2/neu DAKO score 3+, FISH data were available for HER-2/neu. Because some HER-2/neu DAKO score $2+$ cases will be FISH positive for HER-2/neu, we also compared DAKO score 0 or $1+$ with DAKO score $2+$ or $3+$ cases separately. Tumour grading was performed according to the Ellis and Elston grading system. ${ }^{29}$

Using univariate and multivariate analyses, we identified the following factors to predict HER-2/neu status: ER status, PR status, tumour size, tumour grade, axillary lymph node status, and patient's age at diagnosis. The $\chi^{2}$ test was used to examine the categorical variables and the association between HER-2/neu status and other clinicopathological variables in univariate analysis. In multivariate analysis, logistic regression was used to detect the independent factors predicting HER-2/neu overexpression. The frequency of HER2/neu expression according to joint ER/PR status and the distribution of the hormone receptor status (ER, PR, and joint ER/PR) according to HER-2/neu were also calculated. All statistical tests were two sided and $p<0.05$ was considered significant. All statistical analyses were performed with SPSS software version 11.0.1 for Windows (SPSS Inc, Chicago, Illinois, USA).

\section{RESULTS}

Table 1 summarises the clinicopathological features of all 1362 women with primary operable breast cancer. HER-2/neu was overexpressed as defined by a DAKO score $3+$ and a DAKO score $2+$ or $3+$ in $10.9 \%$ and $17.7 \%$ of all patients, respectively. Table 2 shows data for DAKO score $3+$ versus 0 , $1+$, or $2+$ cases. $\mathrm{ER}^{+}$tumours overexpressed HER-2/neu in $6.8 \%$ of cases, and $\mathrm{ER}^{-}$tumours in $28.7 \%$ of cases $(\mathrm{p}<0.001)$. Similarly, women with $\mathrm{PR}^{+}$tumours overexpressed HER-2/neu in $5.9 \%$ of cases, whereas $\mathrm{PR}^{-}$tumours overexpressed HER-2/neu in $19.9 \%$ of cases $(p<0.001)$. Tumour grade also predicted HER-2/neu status: $4.6 \%$ of all grade 1-2 breast cancers overexpressed HER-2/neu compared with $20.8 \%$ of grade 3 lesions $(p<0.001)$. There was no correlation between HER-2/neu status and tumour size, axillary lymph node status, or age at diagnosis (table 2). Multivariate analysis with logistic regression revealed that HER-2/neu overexpression was predicted by ER expression (negative $v$ positive; odds ratio (OR), 2.16; 95\% confidence interval (CI), 1.34 to $3.51 ; \mathrm{p}=0.002)$, $\mathrm{PR}$ expression (negative $v$ positive; $\mathrm{OR}, 1.74 ; 95 \% \mathrm{CI}, 1.10$ to 2.78 ; $\mathrm{p}=0.019$ ), and tumour grade (grade $3 v$ grade $1-2 ;$ OR, 3.27; $95 \%$ CI, 2.12 to $5.05 ; \mathrm{p}<0.001$ ) (table 3). Tables 4 and 5 show these data for HER-2/neu DAKO scores $2+$ or $3+$ versus 0 or $1+$. The results are similar to those for HER-2/neu DAKO scores $3+$ versus $0,1+$, or $2+$. However, the predictors for HER-2/neu overexpression in the multivariate modelER, PR, and tumour grade-have a higher OR when using DAKO score $3+$ cases against $0-2+$ rather than DAKO scores
Table 1 Clinicopathological features $(n=1362)$

\begin{tabular}{|c|c|c|}
\hline & $\mathrm{N}$ & $\%$ \\
\hline \multicolumn{3}{|l|}{ HER-2/neu status* } \\
\hline Negative (score $0,1+$ ) & 1121 & $82.3 \%$ \\
\hline Positive (score $2+, 3+$ ) & 241 & $17.7 \%$ \\
\hline \multicolumn{3}{|l|}{ HER-2/neu status $\dagger$} \\
\hline Negative (score $0,1+, 2+$ ) & 1213 & $89.1 \%$ \\
\hline Positive (score 3+) & 149 & $10.9 \%$ \\
\hline \multicolumn{3}{|l|}{ ER expression‡ } \\
\hline Negative & 258 & $18.9 \%$ \\
\hline Positive & 1104 & $81.1 \%$ \\
\hline \multicolumn{3}{|l|}{ PR expression $\ddagger$} \\
\hline Negative & 488 & $35.8 \%$ \\
\hline Positive & 874 & $64.2 \%$ \\
\hline \multicolumn{3}{|l|}{ Tumour grade } \\
\hline $1-2$ & 828 & $60.8 \%$ \\
\hline 3 & 534 & $39.2 \%$ \\
\hline \multicolumn{3}{|l|}{ Tumour size } \\
\hline$\leqslant 20 \mathrm{~mm}$ & 721 & $52.9 \%$ \\
\hline$>20 \mathrm{~mm}$ & 641 & $47.1 \%$ \\
\hline \multicolumn{3}{|l|}{ Lymph node } \\
\hline Negative & 880 & $64.6 \%$ \\
\hline Positive & 482 & $35.4 \%$ \\
\hline \multicolumn{3}{|l|}{ Age } \\
\hline$\leqslant 50$ years & 429 & $31.5 \%$ \\
\hline$>50$ years & 933 & $68.5 \%$ \\
\hline Total & 1362 & $100.0 \%$ \\
\hline \multicolumn{3}{|c|}{$\begin{array}{l}\text { *HER- } 2 / \text { neu was defined as negative when the DAKO score was } 0 \text { or } 1+ \\
\text { and positive when } 2+\text { or } 3+;+H E R-2 / \text { neu was defined as negative wher } \\
\text { the DAKO score was } 0,1+\text {, or } 2+\text {, and positive when } 3+; \neq E R \text { and PR } \\
\text { were defined as negative when the } H \text { score was } \leqslant 50 \text {, and positive wher } \\
51-300 \text {. } \\
\text { ER, oestrogen receptor; PR, progesterone receptor. }\end{array}$} \\
\hline
\end{tabular}

$2+$ or $3+$ against $0-1+$ cases. Tables 6 and 7 show the frequency of HER-2/neu positivity (DAKO score $3+$ ) in the different ER/PR phenotypes $\left(\mathrm{ER}^{-} \mathrm{PR}^{-}, \mathrm{ER}^{-} \mathrm{PR}^{+}, \mathrm{ER}^{+} \mathrm{PR}^{-}\right.$, and $\mathrm{ER}^{+} \mathrm{PR}^{+}$) of breast cancer and for low and high tumour grade lesions. Differences in HER-2/neu expression between the $\mathrm{ER}^{-} \mathrm{PR}^{-}, \mathrm{ER}^{+} \mathrm{PR}^{-}$, and $\mathrm{ER}^{+} \mathrm{PR}^{+}$phenotypes were significant $(\mathrm{p}<0.001)$. The frequency of HER-2/neu overexpression decreased significantly from $\mathrm{ER}^{-} \mathrm{PR}^{-}$to $\mathrm{ER}^{+} \mathrm{PR}^{-}(28.8 \%$ to

Table 2 Factors predicting HER-2/neu overexpression in primary operable breast cancers $(n=1362)$ : univariate analysis

\begin{tabular}{|c|c|c|c|c|}
\hline & \multicolumn{2}{|c|}{ HER-2/neu expression* } & \multirow{2}{*}{$\begin{array}{l}\text { Odds } \\
\text { ratiot }\end{array}$} & \multirow[b]{2}{*}{ p Value } \\
\hline & Negative & Positive & & \\
\hline \multicolumn{5}{|l|}{ ER statusf } \\
\hline Negative & $184(71.3 \%)$ & $74(28.7 \%)$ & 5.52 & \multirow[t]{2}{*}{$<0.001$} \\
\hline Positive & $1029(93.2 \%)$ & $75(6.8 \%)$ & & \\
\hline \multicolumn{5}{|l|}{ PR status $\ddagger$} \\
\hline Negative & 391 (80.1\%) & $97(19.9 \%)$ & 3.92 & \multirow[t]{2}{*}{$<0.001$} \\
\hline Positive & $822(94.1 \%)$ & $52(5.9 \%)$ & 1 & \\
\hline \multicolumn{5}{|l|}{ Tumour grade } \\
\hline $1-2$ & 790 (95.4\%) & $38(4.6 \%)$ & 1 & \multirow[t]{2}{*}{$<0.001$} \\
\hline 3 & $423(79.2 \%)$ & $111(20.8 \%)$ & 5.46 & \\
\hline \multicolumn{5}{|l|}{ Tumour size } \\
\hline$\leqslant 20 \mathrm{~mm}$ & $645(89.5 \%)$ & $76(10.5 \%)$ & 1 & \multirow[t]{2}{*}{0.617} \\
\hline$>20 \mathrm{~mm}$ & $568(88.6 \%)$ & $73(11.4 \%)$ & 1.09 & \\
\hline \multicolumn{5}{|l|}{ Lymph node } \\
\hline Negative & $790(89.8 \%)$ & $90(10.2 \%)$ & 1 & \multirow[t]{2}{*}{0.255} \\
\hline Positive & $423(87.8 \%)$ & $59(12.2 \%)$ & 1.22 & \\
\hline \multicolumn{5}{|l|}{ Age } \\
\hline$\leqslant 50$ years & $377(87.9 \%)$ & $52(12.1 \%)$ & 1.19 & \multirow[t]{2}{*}{0.344} \\
\hline$>50$ years & $836(89.6 \%)$ & $97(10.4 \%)$ & 1 & \\
\hline
\end{tabular}

Data are number of patients (\%).

*HER-2/neu was defined as negative when the DAKO score was $0,1+$, or $2+$ and positive when $3+$; todds ratio adjusted for all variables in table; $¥ E R$ and PR were defined as negative when the $\mathrm{H}$ score was $\leqslant 50$, and positive when 51-300.

$E R$, oestrogen receptor; PR, progesterone receptor. 
Table 3 Factors predicting HER-2/neu overexpression* in primary operable breast cancers $(n=1362)$ : multivariate analysis

\begin{tabular}{llr}
\hline & Odds ratio $(95 \% \mathrm{Cl})$ & $\mathrm{p}$ Value \\
\hline ER status $¥$ (negative $v$ positive) & $2.16(1.34$ to 3.51$)$ & 0.002 \\
PR status $¥$ (negative $v$ positive) & $1.74(1.10$ to 2.78$)$ & 0.019 \\
Tumour grade (grade $3 v 1-2)$ & $3.27(2.12$ to 5.05$)$ & $<0.001$ \\
Tumour size $(>20 \mathrm{~mm} v \leqslant 20 \mathrm{~mm})$ & - & 0.351 \\
Lymph node (positive $v$ negative) & - & 0.646 \\
Age $(>50$ years $v \leqslant 50$ years) & - & 0.989 \\
\hline
\end{tabular}

*HER-2/neu was defined as negative when the DAKO score was $0,1+$, or $2+$ and positive when $3+$; todds ratio adjusted for all variables in table; †ER and PR were defined as negative when the $\mathrm{H}$ score was $\leqslant 50$, and positive when $51-300$.

$\mathrm{Cl}$, confidence interval; ER, oestrogen receptor; PR, progesterone receptor.

$11.5 \% ; \mathrm{p}<0.001)$ and from $\mathrm{ER}^{+} \mathrm{PR}^{-}$to $\mathrm{ER}^{+} \mathrm{PR}^{+}(11.5 \%$ to $5.4 \% ; \mathrm{p}=0.001)$ cases. These data were similar when comparing HER-2/neu DAKO score 0 or $1+$ with HER-2/neu DAKO score $2+$ or $3+$ cases (data not shown). Tables 8 and 9 show the frequency of hormone receptor expression according to HER-2/neu status. HER-2/neu positive tumours are more often hormone receptor negative than HER-2/neu non-overexpressing tumours. Tables 10 and 11 show the predictive value of the clinicopathological factors for HER-2/ neu in women with an $\mathrm{ER}^{+}$breast cancer. In multivariate analysis, PR and tumour grade remained independent predictors for HER-2/neu overexpression in this subgroup of patients with breast cancer. In 41 of the 149 women with a HER-2/neu DAKO score 3+, we obtained FISH data for HER-2/neu gene amplification. All 41 cases were FISH positive.

\section{DISCUSSION}

We compared HER-2/neu overexpression in hormone receptor positive and hormone receptor negative breast cancers, considering ER, PR, and joint ER/PR expression. In a multivariate model, ER negativity, PR negativity, and high

Table 4 Factors predicting HER-2/neu overexpression in primary operable breast cancers $(n=1362)$ : univariate analysis

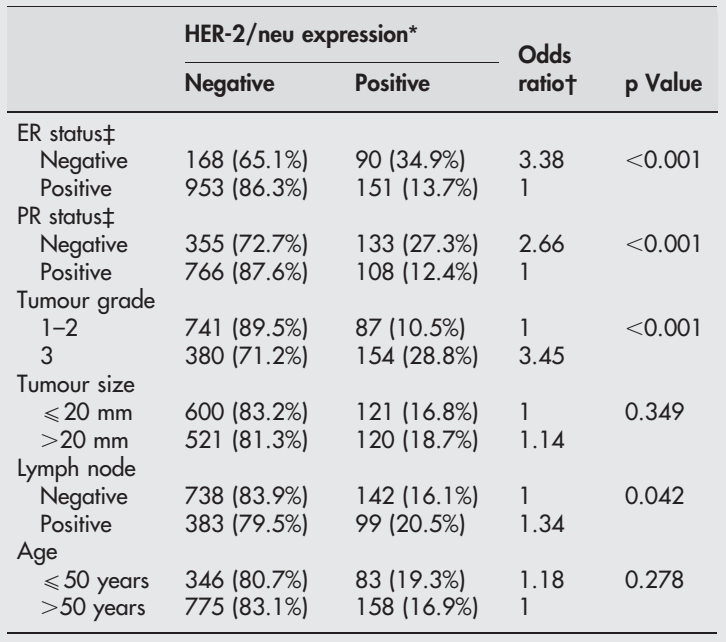

Data are number of patients (\%).

*HER-2/neu was defined as negative when the DAKO score was 0 or $1+$, and positive when $2+$ or $3+$; †odds ratio adjusted for all variables in table; $\neq E R$ and $P R$ were defined as negative when the $\mathrm{H}$ score was $\leqslant 50$, and positive when 51-300.

$E R$, oestrogen receptor; PR, progesterone receptor.
Table 5 Factors predicting HER-2/neu overexpression* in primary operable breast cancers $(n=1362)$ : multivariate analysis

\begin{tabular}{lll}
\hline & Odds ratio† $(95 \% \mathrm{Cl})$ & $\mathbf{p}$ Value \\
\hline ER status $\ddagger$ (negative versus positive) & $1.56(1.03$ to 2.35$)$ & 0.034 \\
PR status $\ddagger$ (negative $v$ positive) & $1.51(1.10$ to 2.25$)$ & 0.014 \\
Tumour grade (grade $3 v 1-2)$ & $2.15(1.81$ to 3.48$)$ & $<0.001$ \\
Tumour size $(>20 v \leqslant 20 \mathrm{~mm})$ & - & 0.670 \\
Lymph node (positive $v$ negative) & - & 0.178 \\
Age $(>50 v \leqslant 50$ years) & - & 0.736 \\
\hline
\end{tabular}

*HER-2/neu was defined as negative when the DAKO score was 0 or $1+$, and positive when $2+$ or $3+$; todds ratio adjusted for all variables in table; $¥ E R$ and $P R$ were defined as negative when the $\mathrm{H}$ score was $\leqslant 50$, and positive when $51-300$

$\mathrm{Cl}$, confidence interval; $\mathrm{ER}$, oestrogen receptor; $\mathrm{PR}$, progesterone receptor.

Table 6 Frequency of HER-2/neu expression by joint $\mathrm{ER} / \mathrm{PR}$ status

\begin{tabular}{|c|c|c|c|c|c|}
\hline & \multicolumn{4}{|c|}{ HER-2/neu expression* } & \multirow[b]{3}{*}{ Total } \\
\hline & \multicolumn{2}{|c|}{ Negative } & \multicolumn{2}{|c|}{ Positive } & \\
\hline & $\bar{N}$ & $\%$ & $\bar{N}$ & $\%$ & \\
\hline $\mathrm{ER}^{-} \mathrm{PR}^{-} \dagger$ & 168 & 71.2 & 68 & 28.8 & 236 \\
\hline $\mathrm{ER}^{-} \mathrm{PR}^{+}$ & 16 & 72.7 & 6 & 27.3 & 22 \\
\hline $\mathrm{ER}^{+} \mathrm{PR}^{-}$ & 223 & 88.5 & 29 & 11.5 & 252 \\
\hline $\mathrm{ER}^{+} \mathrm{PR}^{+}$ & 806 & 94.6 & 46 & 5.4 & 852 \\
\hline Total & 1213 & 89.1 & 149 & 10.9 & 1362 \\
\hline
\end{tabular}

*HER-2/neu was defined as negative when the DAKO score was $0,1+$, or $2+$ and positive when $3+; \nmid E R$ or $P R$ was defined as negative when the $\mathrm{H}$ score was $\leqslant 50$, and positive when $51-300$.

$E R$, oestrogen receptor; $P R$, progesterone receptor.

tumour grade were independent predictors of HER-2/neu positivity. In the subgroup of women with an $\mathrm{ER}^{+}$tumour, PR negativity remained an independent predictor for HER-2/neu overexpression. For the joint ER/PR subgroup, the likelihood of a positive HER-2/neu status decreased significantly from $\mathrm{ER}^{-} \mathrm{PR}^{-}$to $\mathrm{ER}^{+} \mathrm{PR}^{-}$and from $\mathrm{ER}^{+} \mathrm{PR}^{-}$to $\mathrm{ER}^{+} \mathrm{PR}^{+}$cases.

The presence of ER and oestrogen in human breast cancer cell lines results in a reduction of the concentration of the neu protein. ${ }^{30}$ The inverse association between steroid hormone receptors and HER-2/neu has also been described in clinical studies. ${ }^{891112}$ Most studies on this inverse

Table 7 Frequency of HER-2/neu expression for tumour grade 1-2 and grade 3 lesions by joint ER/PR status

\begin{tabular}{|c|c|c|c|c|c|c|}
\hline & \multicolumn{3}{|c|}{ Grade 1-2 } & \multicolumn{3}{|l|}{ Grade 3} \\
\hline & \multicolumn{2}{|c|}{ HER-2/neu* } & \multirow[b]{2}{*}{ Total } & \multicolumn{2}{|c|}{ HER-2/neu* } & \multirow[b]{2}{*}{ Total } \\
\hline & $\mathrm{N}$ & Positive & & $\mathbf{N}$ & Positive & \\
\hline $\mathrm{ER}^{-} \mathrm{PR}^{-} \dagger$ & $\begin{array}{l}20 \\
(69.0 \%)\end{array}$ & $\begin{array}{l}9 \\
(31.0 \%)\end{array}$ & 29 & $\begin{array}{l}148 \\
(71.5 \%)\end{array}$ & $\begin{array}{l}59 \\
(28.5 \%)\end{array}$ & 207 \\
\hline $\mathrm{ER}^{-} \mathrm{PR}^{+}$ & $\begin{array}{l}9 \\
(100.0 \%)\end{array}$ & $\begin{array}{l}0 \\
(0.0 \%)\end{array}$ & 9 & $\begin{array}{l}7 \\
(53.8 \%)\end{array}$ & $\begin{array}{l}6 \\
(46.2 \%)\end{array}$ & 13 \\
\hline $\mathrm{ER}^{+} \mathrm{PR}^{-}$ & $\begin{array}{l}150 \\
(92.6 \%)\end{array}$ & $\begin{array}{l}12 \\
(7.4 \%)\end{array}$ & 162 & $\begin{array}{l}73 \\
(81.1 \%)\end{array}$ & $\begin{array}{l}17 \\
(18.9 \%)\end{array}$ & 90 \\
\hline $\mathrm{ER}^{+} \mathrm{PR}^{+}$ & $\begin{array}{l}611 \\
(97.3 \%)\end{array}$ & $\begin{array}{l}17 \\
(2.7 \%)\end{array}$ & 628 & $\begin{array}{l}195 \\
(87.1 \%)\end{array}$ & $\begin{array}{l}29 \\
(12.9 \%)\end{array}$ & 224 \\
\hline Total & $\begin{array}{l}790 \\
(95.4 \%)\end{array}$ & $\begin{array}{l}38 \\
(4.6 \%)\end{array}$ & 828 & $\begin{array}{l}423 \\
(79.2 \%)\end{array}$ & $\begin{array}{l}111 \\
(20.8 \%)\end{array}$ & 534 \\
\hline
\end{tabular}

Data are numbers of patients (\%).

*HER-2/neu was defined as negative when the DAKO score was $0,1+$, or $2+$ and positive when $3+; \nmid E R$ or $P R$ was defined as negative when the $\mathrm{H}$ score was $\leqslant 50$, and positive when $51-300$.

$E R$, oestrogen receptor; $P R$, progesterone receptor. 
Table 8 Frequency of ER or PR expression by HER-2/ neu status

\begin{tabular}{|c|c|c|c|c|c|}
\hline \multirow{2}{*}{$\begin{array}{l}\text { HER-2/ } \\
\text { neu* }\end{array}$} & \multicolumn{2}{|l|}{ ER† } & \multicolumn{2}{|l|}{ PR† } & \multirow[b]{2}{*}{ Total } \\
\hline & Negative & Positive & Negative & Positive & \\
\hline Negative & $\begin{array}{l}184 \\
(15.2 \%)\end{array}$ & $\begin{array}{l}1029 \\
(84.8 \%)\end{array}$ & $\begin{array}{l}391 \\
(32.2 \%)\end{array}$ & $\begin{array}{l}822 \\
(67.8 \%)\end{array}$ & 1213 \\
\hline Positive & $\begin{array}{l}74 \\
(49.7 \%)\end{array}$ & $\begin{array}{l}75 \\
(50.3 \%)\end{array}$ & $\begin{array}{l}97 \\
(65.1 \%)\end{array}$ & $\begin{array}{l}52 \\
(34.9 \%)\end{array}$ & 149 \\
\hline Total & $\begin{array}{l}258 \\
(18.9 \%)\end{array}$ & $\begin{array}{l}1104 \\
\text { (81.1\%) }\end{array}$ & $\begin{array}{l}488 \\
(35.8 \%)\end{array}$ & $\begin{array}{l}874 \\
(64.2 \%)\end{array}$ & 1362 \\
\hline
\end{tabular}

Data are numbers of patients (\%).

*HER-2/neu was defined as negative when the DAKO score was $0,1+$, or $2+$ and positive when $3+; \nmid E R$ or PR was defined as negative when the $\mathrm{H}$ score was $\leqslant 50$, and positive when $51-300$.

$E R$, oestrogen receptor; PR, progesterone receptor.

association have focused on ER or PR alone, and only two studies considered the effect of the absence of PR in women with an $\mathrm{ER}^{+}$tumour. ${ }^{11}{ }^{12}$ Our results confirm the data of Taucher et al on the association between steroid hormone and HER-2/neu receptors using IHC. ${ }^{12} \mathrm{PR}^{-}$breast cancers, even if they are $\mathrm{ER}^{+}$, are more aggressive than the $\mathrm{PR}^{+}$ phenotype. ${ }^{26-28} 31$

$\mathrm{PR}^{-}$tumours, even if they are $\mathrm{ER}^{+}$, are more likely to be of high grade than $\mathrm{PR}^{+}$tumours. ${ }^{26}$ Tumour grade is one of the best predictors for HER-2/neu overexpression, and may therefore interfere with PR as an independent predictor for HER-2/neu. However, our findings showed that this is not the case. We were able to show that PR is an independent predictor for HER-2/neu overexpression in a multivariate model taking other predictors such as tumour grade into account. We agree that the HER-2/neu overexpression rate is low in a large subgroup of patients with breast cancer. ${ }^{12}$ In our study, the population of $\mathrm{ER}^{+}$tumours with a low grade (grade 1-2) comprises $58 \%$ of the entire population and these tumours are HER-2/neu positive in only $3.7 \%$ of cases. In this low grade $\mathrm{ER}^{+}$population, PR is also predictive for HER-2/ neu positivity, which was $2.7 \%$ and $7.4 \%$ in $\mathrm{PR}^{+}$and $\mathrm{PR}^{-}$ tumours, respectively $(p=0.005)$. Therefore, our data on the importance of PR in predicting HER-2/neu overexpression in low and high grade tumour lesions add to the existing data on this topic and show consistency between populations, so that we still believe in the importance of measuring PR in women with an $\mathrm{ER}^{+}$breast cancer, in contrast to recent reports suggesting otherwise. ${ }^{32}$

The inverse association between HER-2/neu and hormone receptors leads to lower or absent hormone receptors in women with HER-2/neu positive breast cancers. This is one of the reasons why women who overexpress HER-2/neu may be resistant to tamoxifen. ${ }^{16-20}$ In women with an $\mathrm{ER}^{+}$breast cancer, HER-2/neu overexpression implies a greater likelihood of the tumour being $\mathrm{PR}^{-}$. Rhodes et al have shown that the $\mathrm{ER}^{+} \mathrm{PR}^{-}$variant is a menopause related phenotype. ${ }^{33}$ Endogenous oestrogen may be too low to upregulate PR and
Table 10 Factors predicting HER-2/neu overexpression in $\mathrm{ER}^{+}$breast cancers $(\mathrm{n}=1104)$ : univariate analysis

\begin{tabular}{|c|c|c|c|c|}
\hline & \multicolumn{2}{|c|}{ HER-2/neu expression* } & \multirow{2}{*}{$\begin{array}{l}\text { Odds } \\
\text { ratiot }\end{array}$} & \multirow[b]{2}{*}{ p Value } \\
\hline & Negative & Positive & & \\
\hline \multicolumn{5}{|l|}{ PR expression $\ddagger$} \\
\hline Negative & $223(88.5 \%)$ & $29(11.5 \%)$ & 2.28 & \multirow[t]{2}{*}{0.001} \\
\hline Positive & $806(94.6 \%)$ & $46(5.4 \%)$ & & \\
\hline \multicolumn{5}{|l|}{ Tumour grade } \\
\hline $1-2$ & 761 (96.3\%) & $29(03.7 \%)$ & 1 & \multirow[t]{2}{*}{$<0.001$} \\
\hline 3 & $268(85.4 \%)$ & $46(14.6 \%)$ & 4.50 & \\
\hline \multicolumn{5}{|l|}{ Tumour size } \\
\hline$\leqslant 20 \mathrm{~mm}$ & $563(93.4 \%)$ & $40(6.6 \%)$ & 1 & \multirow[t]{2}{*}{0.817} \\
\hline$>20 \mathrm{~mm}$ & $466(93.0 \%)$ & $35(7.0 \%)$ & 1.06 & \\
\hline \multicolumn{5}{|l|}{ Lymph node } \\
\hline Negative & $676(93.9 \%)$ & $44(6.1 \%)$ & 1 & \multirow[t]{2}{*}{0.217} \\
\hline Positive & 353 (91.9\%) & $31(8.1 \%)$ & 1.35 & \\
\hline \multicolumn{5}{|l|}{ Age } \\
\hline$\leqslant 50$ years & $299(91.2 \%)$ & $29(8.8 \%)$ & 1.54 & \multirow[t]{2}{*}{0.079} \\
\hline$>50$ years & $730(94.1 \%)$ & $46(5.9 \%)$ & 1 & \\
\hline
\end{tabular}

Data are number of patients (\%).

*HER-2/neu was defined as negative when the DAKO score was $0,1+$, or $2+$ and positive when $3+$; todds ratio adjusted for all variables in table; $¥ E R$ and $P R$ were defined as negative when the $\mathrm{H}$ score was $\leqslant 50$, and positive when 51-300.

$E R$, oestrogen receptor; PR, progesterone receptor.

Table 11 Factors predicting HER-2/neu overexpression* in $\mathrm{ER}^{+}$breast cancers $(n=1104)$ : multivariate analysis

\begin{tabular}{lll}
\hline & Odds ratio† (95\% Cl) & $\mathbf{p ~ V a l u e ~}$ \\
\hline $\begin{array}{l}\text { PR expression } \ddagger \text { (negative } v \\
\text { positive) }\end{array}$ & $2.01(1.22-3.32)$ & 0.006 \\
Tumour grade (grade $3 v 1-2)$ & $4.27(2.62$ to 6.97$)$ & $<0.001$ \\
Tumour size $(>20 v \leqslant 20 \mathrm{~mm})$ & - & 0.300 \\
Lymph node (positive $v$ negative) & - & 0.692 \\
Age $(\leqslant 50 v>50$ years) & - & 0.088
\end{tabular}

*HER-2/neu was defined as negative when the DAKO score was $0,1+$, or $2+$ and positive when $3+$; †odds ratio adjusted for all variables in table; FER and PR were defined as negative when the $\mathrm{H}$ score was $\leqslant 50$, and positive when 51-300.

$\mathrm{Cl}$, confidence interval; $\mathrm{ER}$, oestrogen receptor; $\mathrm{PR}$, progesterone receptor.

repress HER-2/neu by oestrogen binding to ER, so that the inverse association might be restricted to postmenopausal women. Recently, it has been shown that the $\mathrm{ER}^{+} \mathrm{PR}^{-}$ phenotype is predictive of tamoxifen resistance in postmenopausal women. $\mathrm{ER}^{+} \mathrm{PR}^{-}$tumours have a higher response to aromatase inhibitors and no further response beyond two years of tamoxifen use compared with the $\mathrm{ER}^{+} \mathrm{PR}^{+}$phenotype. ${ }^{34} 35$ However, these randomised controlled studies did not associate HER-2/neu positivity with the $\mathrm{ER}^{+} \mathrm{PR}^{-}$phenotype, but our findings and those of others suggest this as one of the underlying mechanisms for

Table 9 Frequency of joint ER/PR expression by HER-2/neu status

\begin{tabular}{|c|c|c|c|c|c|}
\hline \multirow[b]{2}{*}{ HER-2/neu* } & \multicolumn{4}{|l|}{ Joint ER/PR† } & \multirow[b]{2}{*}{ Total } \\
\hline & $\mathrm{ER}^{-} \mathrm{PR}^{-}$ & $\mathrm{ER}^{-} \mathrm{PR}^{+}$ & $\mathrm{ER}^{+} \mathrm{PR}^{-}$ & $\mathrm{ER}^{+} \mathrm{PR}^{+}$ & \\
\hline Negative & $168(13.8 \%)$ & $16(1.3 \%)$ & $223(18.4 \%)$ & $806(66.4 \%)$ & 1213 \\
\hline Positive & $68(45.6 \%)$ & $6(4.0 \%)$ & $29(19.5 \%)$ & $46(30.9 \%)$ & 149 \\
\hline Total & $236(17.3 \%)$ & 22 (1.6\%) & $252(18.5 \%)$ & 852 (62.6\%) & 1362 \\
\hline
\end{tabular}

Data are number of patients (\%).

*HER-2/neu was defined as negative when the DAKO score was $0,1+$, and $2+$ and positive when $3+$; + ER or PR was defined as negative when the $\mathrm{H}$ score was $\leqslant 50$, and positive when $51-300$.

$E R$, oestrogen receptor; $P R$, progesterone receptor. 


\section{Take home messages}

- Using multivariate analysis, we found that the oestrogen receptor (ER), progesterone receptor (PR), and tumour grade were independent predictors of HER-2/ neu overexpression in women with operable breast cancer

- ER and PR were inversely related to HER-2/neu overexpression, whereas tumour grade was positively associated with HER-2/neu overexpression

- In women with $\mathrm{ER}^{+}$tumours, the expression of $\mathrm{PR}$ affects the likelihood of HER-2/neu overexpression, and it may be that women with $\mathrm{ER}^{+} \mathrm{PR}^{-}$tumours should be targeted with more aggressive treatment than those with $\mathrm{ER}^{+} \mathrm{PR}^{+}$tumours

tamoxifen resistance in such patients. This is another reason to measure $\mathrm{PR}$ in women with an $\mathrm{ER}^{+}$tumour. ${ }^{32}$ The mechanism behind PR negativity in premenopausal women with an $\mathrm{ER}^{+}$breast cancer and large amounts of circulating oestrogen is not known, but may be different from that in postmenopausal women. Whether HER-2/neu overexpression also implies a greater likelihood for PR negativity in premenopausal women with an $\mathrm{ER}^{+}$breast cancer is the subject of our own ongoing research, but one study indicated that HER-2/neu overexpression is not a predictor for resistance to antioestrogen treatment in premenopausal women with early breast cancer. ${ }^{36}$

"We were able to show that PR is an independent predictor for HER-2/neu overexpression in a multivariate model taking other predictors such as tumour grade into account $^{\prime \prime}$

Our IHC definition of HER-2/neu positivity has been shown to be comparable to FISH testing for HER-2/neu, ${ }^{22}$ and we found $100 \%$ agreement between IHC $3+$ and FISH gene amplification for HER-2/neu in a small subgroup of women with a FISH result available. A small number of patients with a lower than 3+ score for HER-2/neu may also test positive using FISH. ${ }^{37}$ Most studies on HER-2/neu expression examined HER-2/neu by enzyme linked immunosorbent assay or considered DAKO score $2+$ cases in the group of HER-2/neu positive tumours when using IHC. This may explain why our frequency data for HER-2/neu overexpression are lower than in other reports. When we considered DAKO score $2+$ or $3+$ versus 0 or $1+$ as HER-2/neu positive and negative, respectively, the inverse association between HER-2/neu and hormone receptors remained significant, but the odds ratios of the different variables predicting HER-2/neu positivity were slightly lower. Furthermore, our data are also reliable in that we used a large number of patients from one centre where the scoring analysis was validated by one pathologist (Dr M Drijkoningen).

In conclusion, we examined whether ER, PR, tumour grade, and other clinicopathological factors in all women with breast cancer and in women with an $\mathrm{ER}^{+}$breast cancer were associated with HER-2/neu positivity. We found such a predictive role for ER and PR in a multivariate model also including tumour grade. We suggest that the inverse relation between loss of ER and HER-2/neu overexpression should be extended to loss of PR in $\mathrm{ER}^{+}$breast cancers. Whether women with an $\mathrm{ER}^{+} \mathrm{PR}^{-}$breast cancer need more aggressive treatment or a combination of hormone treatment and
anti-HER-2/neu antibodies in contrast to women with an $\mathrm{ER}^{+} \mathrm{PR}^{+}$breast cancer will become clear from the results of major breast cancer treatment trials taking all these different variables into consideration.

\section{Authors' affiliations}

H J Huang, Division of Gynaecological Oncology in Department of Obstetrics and Gynaecology, Chang Gung Memorial Hospital, 333 Taoyuan, Taiwan

P Neven, F Amant, Division of Gynaecological Oncology in Department of Obstetrics and Gynaecology and Multidisciplinary Breast Centre, Leuven University Hospital, 3000 Leuven, Belgium

P Berteloot, I Vergote, Division of Gynaecologic Oncology in

Department of Obstetrics and Gynaecology, Leuven University Hospital M Drijkoningen, Department of Pathology and Multidisciplinary Breast Centre, Leuven University Hospital

R Paridaens, H Wildiers, Department of Medical Oncology and Multidisciplinary Breast Centre, Leuven University Hospital

E Van Limbergen, Department of Radiotherapy and Multidisciplinary Breast Centre, Leuven University Hospital

M R Christiaens, Department of Surgery and Multidisciplinary Breast Centre, Leuven University Hospital

\section{REFERENCES}

1 Akiyama T, Sudo C, Ogawara $\mathrm{H}$, et al. The product of the human c-erbB-2 gene: a 185-kilodalton glycoprotein with tyrosine kinase activity. Science 1986;232: 1644-6.

2 Benz CC, Scott GK, Sarup JC, et al. Estrogen-dependent, tamoxifen-resistant tumorigenic growth of MCF-7 cells transfected with HER2/neu. Breast Cancer Res Treat 1993:24:85-95.

3 Slamon DJ, Clark GM, Wong SG, et al. Human breast cancer: correlation of relapse and survival with amplification of the HER-2/neu oncogene. Science 1987;235:177-82.

4 Gusterson BA, Gelber RD, Goldhirsch A, et al. Prognostic importance of c-erbB-2 expression in breast cancer. J Clin Oncol 1992;10:1049-56.

5 Kronqvist $\mathbf{P}$, Kuopio T, Nykanen $M$, et al. Predicting aggressive outcome in TINOMO breast cancer. Br J Cancer 2004;9:277-81.

6 Bull SB, Ozcelik H, Pinnaduwage D, et al. The combination of p53 mutation and neu/erbB-2 amplification is associated with poor survival in nodenegative breast cancer. J Clin Oncol 2004;22:86-96.

7 Siogren S, Inganas M, Lindgren A, et al. Prognostic and predictive value of c-erbB-2 overexpression in primary breast cancer, alone and in combination with other prognostic markers. J Clin Oncol 1998;16:462-9.

8 Zeillinger R, Kury F, Czerwenka K, et al. HER-2 amplification, steroid receptors and epidermal growth factor receptor in primary breast cancer. Oncogene 1989;4:109-14.

9 Marsigliante S, Muscella A, Ciardo V, et al. Enzyme-linked immunosorbent assay of HER-2/neu gene product (p185) in breast cancer: its correlation with sex steroid receptors, cathepsin D and histologic grades. Cancer Lett 1993;75:195-206

10 Quenel N, Wafflart J, Bonichon F, et al. The prognostic value of c-erbB2 in primary breast carcinomas: a study on 942 cases. Breast Cancer Res Treat 1995;35:283-91.

11 Konecny G, Pauletti G, Pegram M, et al. Quantitative association between HER-2/neu and steroid hormone receptors in hormone receptor-positive primary breast cancer. J Nat Cancer Inst 2003;95:142-53.

12 Taucher S, Rudas M, Mader RM, et al. Do we need HER-2/neu testing for all patients with primary breast carcinoma? Cancer 2003;98:2547-53.

13 van de Vijver MJ, Peterse JL, Mooi WJ, et al. Neu-protein overexpression in breast cancer. Association with comedo-type ductal carcinoma in situ and limited prognostic value in stage II breast cancer. N Engl J Med 1988:319: 1239-45.

14 Chang K, Ding I, Kern FG, et al. Immunohistochemical analysis of p53 and HER-2/neu proteins in human tumors. J Histochem Cytochem 1991;39:1281-7

15 Varga Z, Zhao J, Ohlschlegel C, et al. Preferential HER-2/neu overexpression and/or amplification in aggressive histological subtypes of invasive breast cancer. Histopathology 2004;44:332-8.

16 Wright C, Nicholson S, Angus B, et al. Relationship between c-erbB-2 protein product expression and response to endocrine therapy in advanced breast cancer. Br J Cancer 1992;65:118-21.

17 Leitzel K, Teramoto Y, Konrad K, et al. Elevated serum c-erbB-2 antigen levels and decreased response to hormone therapy of breast cancer. J Clin Oncol 1995;13:1129-35.

18 Carlomagno C, Perrone F, Gallo C, et al. c-erbB-2 overexpression decreases the benefit of adjuvant tamoxifen in early-stage breast cancer without axillary lymph node metastases. J Clin Oncol 1996; 14:2702-8.

19 Ellis MJ, Coop A, Singh B, et al. Letrozole is more effective neoadjuvant endocrine therapy than tamoxifen for ErbB-1-and/or ErbB-2-positive, estrogen receptor-positive primary breast cancer: evidence from a phase III randomized trial. J Clin Oncol 2001;19:3808-16.

20 Lipton A, Ali SM, Leitzel K, et al. Elevated serum HER-2/neu levels predict decreased response to hormone therapy in metastatic breast cancer. J Clin Oncol 2002;20:1467-72. 
21 Elledge R, Green S, Ciocca DR, et al. HER-2 expression and response to tamoxifen in estrogen receptor-positive breast cancer: a southwest oncology group study. Clin Cancer Res 1998;4:7-12.

22 Yaziii H, Goldstein LC, Barry TS, et al. HER-2 testing in breast cancer using parallel tissue-based methods. JAMA 2004;291:1972-7.

23 Arteaga CL, Winnier AR, Poirier MC, et al. p185c-erbB-2 signal enhances cisplatin-induced cytotoxicity in human breast carcinoma cells: association between an oncogenic receptor tyrosine kinase and drug-induced DNA repair. Cancer Res 1994:54:3758-65.

24 Pegram MD, Lipton A, Hayes DF, et al. Phase II study of receptor-enhanced chemosensitivity using recombinant humanized anti-p185 Her-2/neu monoclonal antibody plus cisplatin in patients with HER2/neu overexpressing metastatic breast cancer refractory to chemotherapy treatment. J Clin Onco 1998;16:2659-71.

25 Slamon DJ, Leyland-Jones B, Shak S, et al. Use of chemotherapy plus a monoclonal antibody against HER2 for metastatic breast cancer that overexpresses HER2. N Engl J Med 2001;344:783-92.

26 Thoresen S, Thorsen T, Tangen M, et al. Oestrogen and progesterone receptor content and the distribution of histological grade in breast cancer. Breast Cancer Res Treat 1982;2:251-5.

27 Bardou VJ, Arpino G, Elledge RM, et al. Progesterone receptor status significantly improves outcome prediction over estrogen receptor status alone for adjuvant endocrine therapy in two large breast cancer databases. J Clin Oncol 2003;21:1973-9.

28 Mohsin SK, Weiss H, Havighurst T, et al. Progesterone receptor by immunohistochemistry and clinical outcome in breast cancer: a validation study. Mod Pathol 2004; 17:1545-54.

29 Elston EW, Ellis IO. Method for grading breast cancer. J Clin Pathol 1993:46:189-90.
30 Russell KS, Hung MC. Transcriptional repression of the neu protooncogene by estrogen stimulated estrogen receptor. Cancer Res 1992;52:6624-9.

31 Anderson WF, Chu KC, Chatterjee N, et al. Tumor variants by hormone receptor expression in white patients with node-negative breast cancer from the surveillance, epidemiology, and end results database. J Clin Oncol 2001;19:18-27.

32 Olivotto IA, Truong PT, Speers $\mathrm{CH}$, et al. Time to stop progesterone receptor testing in breast cancer management. J Clin Oncol 2004;22:1769-70.

33 Rhodes A, Jasani B, Balaton AJ, et al. Frequency of oestrogen and progesterone receptor positivity by immunohistochemical analysis in 7016 breast carcinomas: correlation with patient age, assay sensitivity, threshold value, and mammographic screening. J Clin Pathol 2000;53:688-96

34 Dowsett $M$ on behalf of the ATAC Trialists' Group. Analysis of time to recurrence in the ATAC trial according to estrogen and progesterone receptor status [abstract]. Breast Cancer Res Treat 2003;82(suppl 1):S7.

35 Ferno M, Stal O, Baldetorp B, et al. Results of two or five years of adjuvant tamoxifen correlated to steroid receptor and S-phase levels. South Sweden breast cancer group, and south-east Sweden breast cancer group. Breast Cancer Res Treat 2000:59:69-76.

36 Love RR, Duc NB, Havighurst TC, et al. Her-2/neu overexpression and response to oophorectomy plus tamoxifen adjuvant therapy in estrogen receptor-positive premenopausal women with operable breast cancer. J Clin Oncol 2003;21:453-7.

37 Hammock L, Lewis $M$, Phillips $C$, et al. Strong HER-2/neu protein overexpression by immunohistochemistry often does not predict oncogene amplification by fluorescence in situ hybridization. Hum Pathol 2003;34:1043-7.

\section{Call for papers}

11 th European Forum on Quality Improvement in Health Care 26-28 April 2006, Prague, Czech Republic

Deadline 30 September 2005.

For further information and to submit online go to: www.quality.bmipg.com 